\title{
Enzymeimmunoassay of oestradiol, testosterone and progesterone in urine samples from female mice before and after insemination
}

\author{
D. deCatanzaro ${ }^{1}$, C. Muir ${ }^{2,3}$, E. Beaton ${ }^{1}$, M. Jetha ${ }^{1}$ and K. Nadella ${ }^{1,4}$ \\ ${ }^{1}$ Department of Psychology, McMaster University, Hamilton, Ontario, Canada; ${ }^{2}$ Department of \\ Immunology, CIDtech Research, Cambridge, Ontario, Canada; ${ }^{3}$ Department of Psychology, \\ Brock University, St Catharines, Ontario, Canada; and ${ }^{4}$ Department of Biochemistry, \\ McMaster University, Hamilton, Ontario, Canada
}

\begin{abstract}
ELISA measurements of $17 \beta$-oestradiol, testosterone and progesterone were determined for urine samples collected non-invasively from female mice. Initial samples were collected during 5 successive days while mature female mice were isolated and cyclic. Subsequently, female mice were inseminated and additional urine samples were collected during days 2-6 after observation of copulatory plugs. Measurements of oestradiol and testosterone showed variance over days within individuals and did not significantly differ in measurements taken before or after
\end{abstract}

insemination. Progesterone concentrations were significantly higher after insemination compared with before mating. In a second sample of inseminated females, urinary progesterone was measured during days 2-18 of pregnancy. Most females showed high urinary progesterone up to day 10 of pregnancy and lower concentrations during the remainder of gestation. These results indicate that urinary progesterone reflects established systemic increases of this hormone during pregnancy.

\section{Introduction}

Non-invasive methods have been developed for measuring steroids in excretions of mice, permitting repeated measurements that give profiles of individuals over time and in different conditions (Muir et al., 2001; Vella and deCatanzaro, 2001). Repeated blood sampling for measurements of steroids can be impractical in small species, as sampling can interfere with subsequent measurement and may require the animal to be killed. Studies over time are thus not possible unless indirect means or cross-sectional multi-subject designs are used and these can obscure individual differences. Enzymelinked immunosorbent assays (ELISA), previously applied to larger mammals in field and zoo studies, (for example, see Carroll et al., 1990; Munro et al., 1991; Brown et al., 1994; Graham et al., 1995), have been adapted for use in mice. Muir et al. (2001) presented validations of methods for oestradiol, testosterone and oestrone conjugates for excretions from laboratory mice. The results indicate the substantial presence of unconjugated oestradiol and testosterone in urine and faeces of both male and female mice, but oestroneconjugate concentrations were relatively low in female mice and undetectable in male mice. Vella and deCatanzaro (2001) measured systematic declines of oes-

Email: decatanz@univmail.cis.mcmaster.ca tradiol and testosterone in male urine during the initial weeks after castration.

The present study was designed to examine steroid concentrations in urine during pregnancy. The first study focused on the concentrations of steroids during early pregnancy at about the time of intrauterine implantation of fertilized ova and compared these values with concentrations before insemination. In addition to measurements of oestradiol and testosterone, an assay of progesterone was validated and this steroid was measured. Individual differences in steroid dynamics during early gestation are of interest due to the sensitivity of implantation to steroid variations and the experience of the female. Early pregnancy is vulnerable to diverse environmental and social events (for example, see Hsu, 1948; Bruce, 1960; Wiebold et al., 1986; deCatanzaro, 1988; deCatanzaro and MacNiven, 1992; deCatanzaro et al., 1996). Although oestrogen activity is clearly important for the induction of oestrus (Pfaff, 1980) and preparation of the uterus for implantation (Harper, 1992), small increases above optimal circulating concentrations can disrupt intrauterine implantation (Harper, 1969; deCatanzaro et al., 1991; 2001), whereas exogenous oestrogen antibodies can reduce vulnerability of implantation to factors such as restraint stress and exposure to novel males (deCatanzaro et al., 1994, 1995). Exogenous androgens can also disrupt implantation, probably as a result of metabolism to oestrogens (Harper, 1969; 
deCatanzaro et al., 1991, 2001). Progesterone is also clearly of interest given the well-known dependency of gestation upon the actions of this steroid (for example, see Runner, 1959; Pepe and Rothchild, 1974; Barkley et al., 1979). In the second study, individual profiles of progesterone were determined throughout gestation.

\section{Materials and Methods}

\section{Animals}

CF-1 strain mice were bred from stock originally obtained from the Charles River Breeding Farms (La Prairie, Quebec). They were weaned at 30 days of age, and then housed in groups of four or five in standard polypropylene cages measuring $28 \mathrm{~cm} \times 16 \mathrm{~cm} \times 11 \mathrm{~cm}$ (height) with wire bar tops allowing constant access to food and water. Female mice remained in these groups before the start of the experiment and were sexually inexperienced. Male mice were housed individually after weaning, were sexually experienced and were of proven fertility, and were 6-10 months of age when used for insemination. The animal colony was maintained at $21^{\circ} \mathrm{C}$ with a reversed $14 \mathrm{~h}: 10 \mathrm{~h}$ light:dark photoperiod.

This research was approved by the Animal Research Ethics Board of McMaster University, conforming to the standards of the Canadian Council on Animal Care.

\section{Urine sampling before insemination}

At approximately day 120 of age, 25 female mice were each isolated in a clear Plexiglas apparatus, measuring $30 \mathrm{~cm} \times 21 \mathrm{~cm} \times 13 \mathrm{~cm}$ (height), with a stainless steel wire-grid floor with open squares measuring $0.5 \mathrm{~cm}$. The floor was raised approximately $1 \mathrm{~cm}$ above a clean flat stainless steel surface. Each animal had continuous access to food and water. During the first 4 days in the apparatus, female mice were completely undisturbed to allow adaptation to isolation and the apparatus. On day 5, approximately $1 \mathrm{~h}$ after commencement of the dark phase of the photoperiod, urine samples were collected from each female. This procedure was repeated each day for 5 successive days. Urine samples were obtained without handling the mice by lifting the apparatus away from the stainless steel floor, and then aspirating urine from pools left by the mice with a 1 cc syringe with a 26-gauge needle. Approximately $500 \mu$ l of urine was collected per mouse per day. Care was taken to ensure that urine samples were not contaminated with faeces. All samples were stored after collection in coded scintillation vials at $-20^{\circ} \mathrm{C}$.

\section{Insemination, subsequent collection of urinary samples and parturition measurements}

Three days after the last collection of urine before insemination, each female was transferred to the home cage of a male mouse. The hindquarters of each female were inspected on three occasions each day $(1,5$ and $9 \mathrm{~h}$ after commencement of the dark phase of the photoperiod) for copulatory plugs. Plugs were found for eight females on day 1 , four females on day 2 , three females on day 3 and five females day 4 after housing with the male. Immediately after detection of a copulatory plug, each female was returned to the urine collection apparatus. One other female mouse was eliminated from the experiment due to poor health; four other female mice were eliminated because copulatory plugs were not detected. Accordingly, 20 inseminated female mice were each in a urine collection apparatus. Five additional daily collections of urine were conducted for each inseminated female on days 2-6 after detection of the copulatory plug, using the methods described for collections before insemination. After the fifth collection of urine after insemination, each female was removed from the collection apparatus, housed individually in a standard mouse cage with nesting material and left undisturbed until pregnancy outcome measurements were taken. Commencing on day 18 and continuing until day 25 after detection of the copulatory plug, each female was examined on three occasions each day for occurrence of birth. The number of live pups, the number of stillbirths and cannibalizations were recorded.

\section{Urine progesterone throughout gestation}

Given the results from the first study indicating that urine progesterone increased in early pregnancy, a second study was conducted to determine the concentration of urinary progesterone throughout pregnancy. Six female mice were mated to males as described above and then placed at approximately $24 \mathrm{~h}$ after detection of a copulatory plug in urine collection cages similar to those described above, except that a Teflon-coated collection surface was used to improve urine sampling. Samples were collected from each female each day at approximately $1 \mathrm{~h}$ after the start of the dark phase of the photoperiod, beginning on day 2 and ending on day 18 after the detection of the copulatory plug.

\section{Assay procedures}

ELISA procedures generally followed those described for other mammals (Munro et al., 1991); validations for this laboratory for adult male and female mice are reported by Muir et al. (2001). Coefficients of variation were determined by the methods described by Rodbard and Lewald (1974). For oestradiol, the interplate coefficient of variation was $8.4 \%$ at $30 \%$ bound and $4.1 \%$ at $70 \%$ bound, and the intraplate coefficient of variation was $8.7 \%$. For testosterone, the interplate coefficients of variation were $6.7 \%$ at $30 \%$ bound and $3.4 \%$ at $70 \%$ bound, and the intraplate coefficient of variation was $7.1 \%$. For progesterone, the interplate coefficients of variation were $9.7 \%$ at $30 \%$ bound and $4.1 \%$ at 
$70 \%$ bound, and the intraplate coefficient of variation was $7.4 \%$. Creatinine, $17 \beta$-oestradiol, testosterone and progesterone were obtained from Sigma Chemical Co. (St Louis, MO) Antibodies to 17 $\beta$-oestradiol, testosterone and progesterone and corresponding horseradish peroxidase conjugates were obtained from the Department of Population Health and Reproduction at the University of California (Davis, CA). Crossreactivities according to the criteria of Abraham (1969) for anti-oestradiol are: oestradiol $100 \%$, oestrone $3.3 \%$, progesterone $0.8 \%$, testosterone $1.0 \%$, androstenedione $1.0 \%$ and all other tested steroids $<0.1 \%$. Crossreactivities for anti-testosterone are: testosterone $100.0 \%$, $5 \alpha$-dihydrotestosterone $57.4 \%$, androstenedione $0.27 \%$, and androsterone, dehydroepiandrosterone (DHEA), cholesterol, oestradiol, progesterone and pregnenolone $<0.05 \%$. Crossreactivities for anti-progesterone are: progesterone $100.0 \%, 11 \alpha$-hydroxyprogesterone $45.2 \%$, $5 \alpha$-pregnen-3,20-dione $18.6 \%, 17 \alpha$-hydroxyprogesterone $0.38 \%, 20 \alpha$-hydroxyprogesterone $0.13 \%, 20 \beta$ hydroxyprogesterone $0.13 \%$, pregnanediol $<0.001 \%$, pregnenolone $0.12 \%$, oestradiol $<0.001 \%$ and oestrone $<0.04 \%$.

The assays were carried out on Nunc Maxisorb plates which were first coated with $50 \mu \mathrm{l}$ of antibody stock diluted at 1:10000 in a coating buffer $(50 \mathrm{mmol}$ bicarbonate buffer $\mathrm{I}^{-1}, \mathrm{pH}$ 9.6) and stored for 12-14 h at $4{ }^{\circ} \mathrm{C}$. Wash solution $\left(0.15 \mathrm{~mol} \mathrm{NaCl} \mathrm{I}{ }^{-1}\right.$ containing $0.5 \mathrm{ml}$ of Tween $20^{-1}$ ) was added to each well to rinse away any unbound antibody and then $50 \mu$ l phosphate buffer per well was added. The plates were incubated at room temperature $\left(21^{\circ} \mathrm{C}\right)$ for $2 \mathrm{~h}$ for oestradiol determination, $30 \mathrm{~min}$ for testosterone determination and $1 \mathrm{~h}$ for progesterone determination before adding standards, samples or controls. For oestradiol determination, urine samples were diluted 1:8 in phosphate buffer before they were added to the plate. For testosterone or progesterone assays, urine was diluted 1:4 each in phosphate buffer. For each hormone, two quality control urine samples at 30 and $70 \%$ binding (the low and high ends of the sensitive range of the standard curve) were prepared. For all assays, $50 \mu \mathrm{l}$ oestradiol, testosterone, or progesterone horseradish peroxidase was added to each well, with $20 \mu \mathrm{l}$ of standard, sample, or control for oestradiol or $50 \mu \mathrm{l}$ of standard, sample, or control for testosterone or progesterone. The plates were incubated for $2 \mathrm{~h}$ at room temperature. Subsequently, the plates were washed and $100 \mu \mathrm{l}$ of a substrate solution of citrate buffer, $\mathrm{H}_{2} \mathrm{O}_{2}$ and 2,2'-azino-bis (3-ethylbenzothiazoline-6-sulphonic acid) were added to each well and the plates were covered and incubated while shaking at room temperature for 30$60 \mathrm{~min}$. The plates were then read with a single filter at $405 \mathrm{~nm}$ on the microplate reader (Bio-Tek Instruments Inc. EL 312E). Blank absorbance was subtracted from each reading to account for non-specific binding.

In all assays, absorbances were obtained, standard curves were generated, a regression line was fit to the sensitive range of the standard curve (typically 40 $60 \%$ binding) and samples were interpolated into the equation to get a value in pg per well. Validations for assays of oestradiol and testosterone were provided by Muir et al. (2001). Validations for progesterone were subsequently conducted and reported here. A test for parallelism was conducted to determine whether urine samples perform immunologically in a similar manner to steroid standards. A serial dilution of samples was compared with a standard curve plotted against logarithmically transformed doses. This test indicates whether the steroid is present in samples in measurable quantities, and whether samples react with the antibodies in a predictable manner. In addition, progesterone concentration in urine samples from ovariectomized and intact females were compared. Twelve females were ovariectomized under sodium pentobarbital anaesthesia and Xylocaine at the site of incision. After approximately 1 month, samples of their urine were collected and pooled. Samples of urine from 24 group-housed intact females were also collected and pooled.

On account of variations in fluid intake and output, concentration of urine in experimental samples was adjusted for creatinine. Standard creatinine values of 100.0, 50.0, 25.0, 12.5, 6.25 and $3.12 \mu \mathrm{g} \mathrm{ml}^{-1}$ were used, and distilled water was set at zero. All urine samples are diluted 1:50 urine:phosphate buffer $(0.1 \mathrm{~mol}$ $\mathrm{I}^{-1}$ sodium phosphate buffer, $\mathrm{pH} 7.0$ containing $8.7 \mathrm{~g}$ of $\mathrm{NaCl}$ and $1 \mathrm{~g}$ of BSA per litre). Dynatech Immulon flat bottom plates were used and $50 \mu \mathrm{l}$ per well of standard was added together with $50 \mu \mathrm{l}$ distilled water, $50 \mu \mathrm{l} 0.75 \mathrm{~mol} \mathrm{NaOH} \mathrm{I}^{-1}$ and $50 \mu \mathrm{l} 0.4 \mathrm{~mol}$ picric acid $\mathrm{I}^{-1}$. The plate was then shaken and incubated at room temperature for $30 \mathrm{~min}$. The plate was measured for absorbance on a plate reader with a single filter at $490 \mathrm{~nm}$. Standard curves were generated; regression lines were fit; and the regression equation was applied to the absorbancy for each sample. Steroid measurements were adjusted for creatinine by dividing the value obtained by the measurement of creatinine per $\mathrm{ml}$ of urine for the particular sample.

\section{Results}

The results of a test for parallelism for progesterone that compare serially diluted samples and standards are shown (Fig. 1). A test for parallelism was performed on these two curves (Pedhazur, 1973); application of the regression equation derived from the standard curve fit the urine data as well as did the regression equation predicting urine itself, with almost identical $R^{2}$ values (0.8501 versus 0.8503$)$ for a quadratic fit. Progesterone was able to displace horseradish peroxidase-conjugate binding from $100 \%$ down to $17 \%$ when samples were tested in serial dilutions from 1:512 to 1:1 (urine:buffer). Measurements of urinary progesterone yielded a value 


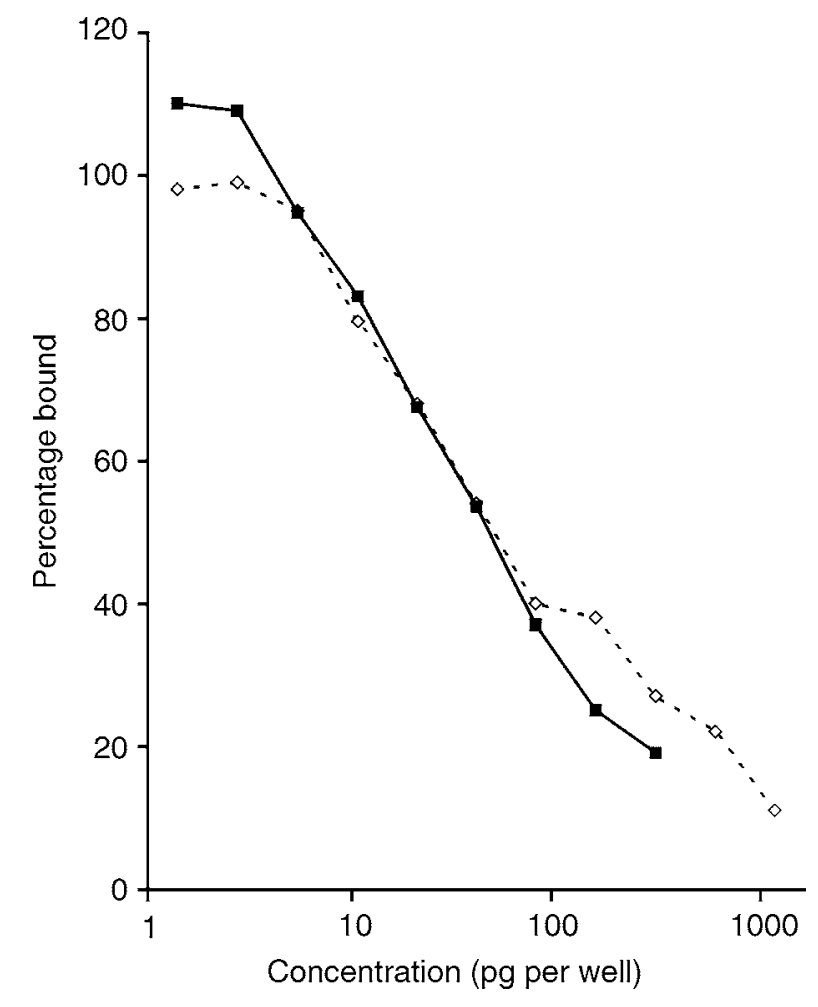

Fig. 1. Serially diluted pooled mouse urine samples binding to antibody in parallel with serially diluted progesterone standards. The abscissa applies only to the standards. $\diamond$ : standard; $\mathbf{\square}$ : urine.

of $16.8 \mathrm{ng} \mathrm{mg}^{-1}$ creatinine for pooled intact females and $4.0 \mathrm{ng} \mathrm{mg}^{-1}$ creatinine for females ovariectomized 1 month previously; a ratio of $4: 1$ or greater was sustained in comparisons of progressive dilutions of the urine. Sensitivity of the progesterone assay was determined by the least amount of hormone that could be distinguished from zero concentration of standard, as calculated from $95 \%$ confidence limits at the zero point of the standard curve. The assay had a range of 2.4-2500.0 pg per well with a minimum sensitivity of $4.8 \mathrm{pg}$ per well $(50 \mu \mathrm{l})$. Recovery curves were generated to assess procedural losses of hormone. Steroid standards were added to pooled urine samples at three different concentrations and extracted for measurement. The average recovery for spiked urine samples was $95.0 \pm 11.0 \%$.

The mean $( \pm$ SE) oestradiol concentration in the five measurements before insemination and during the five measurements on days 2-6 after insemination, including data in both cases from the 20 subjects that had copulatory plugs, is shown (Fig. 2). The corresponding data for measurements of testosterone and progesterone are shown (Figs 3 and 4). The strongest and most obvious effect was a higher overall concentration of progesterone in the urine of female mice after insemination as opposed to before insemination. ANOVA was conducted on each steroid measured for the 20 mice with copulatory plugs, treating day of measurement and the before versus

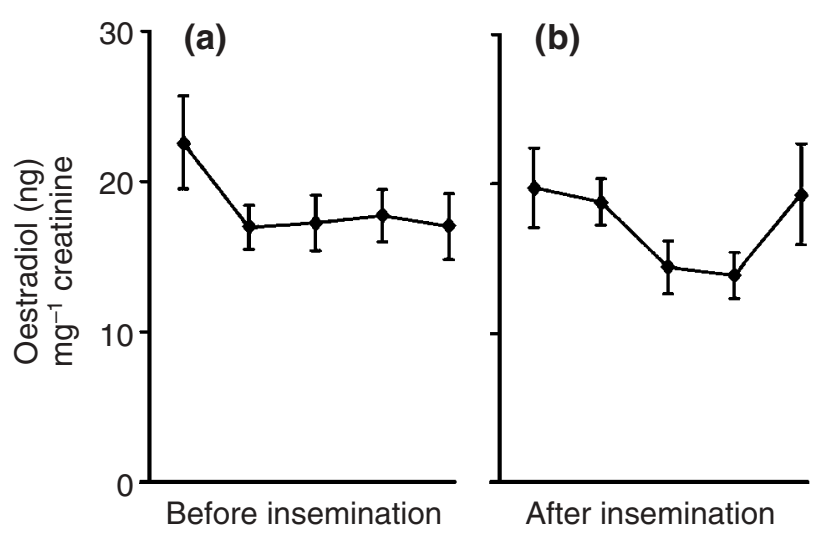

Fig. 2. Mean ( \pm SE) values for oestradiol in (a) the five successive daily urine measurements before insemination and (b) the five measurements on days 2-6 after insemination, for all mice in which copulatory plugs were observed.

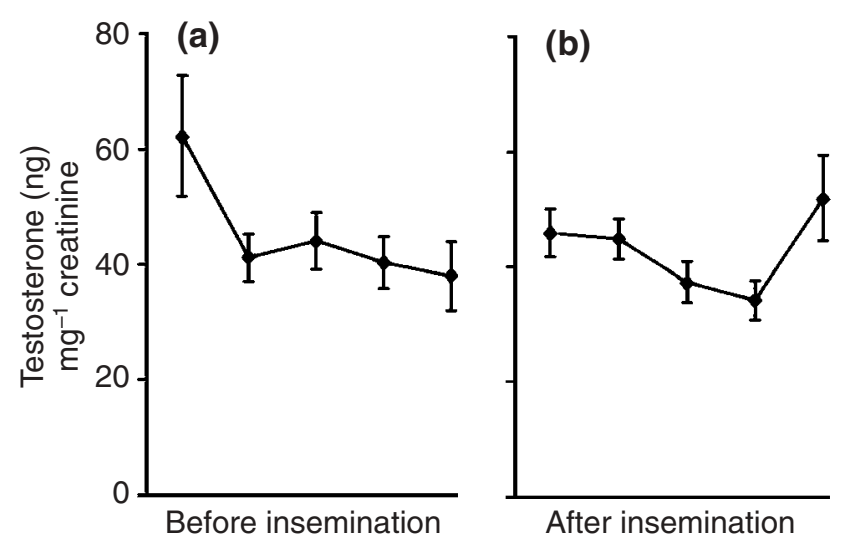

Fig. 3. Mean ( $\pm \mathrm{SE}$ ) values for testosterone in (a) the five successive daily urine measurements before insemination and (b) the five measurements on days 2-6 after insemination, for all mice in which copulatory plugs were observed.
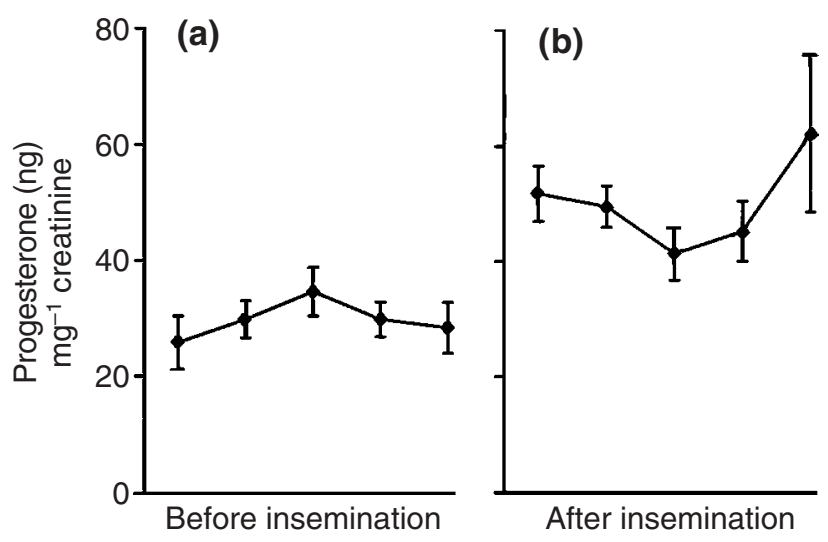

Fig. 4. Mean $( \pm S E)$ values for progesterone in (a) the five successive daily urine measurements before insemination and (b) the five measurements on days $2-6$ after insemination, for all mice in which copulatory plugs were observed. 
Table 1. Pearson product-moment correlations between the number of mice born and steroid measurements on 5 successive days before insemination and 5 successive days after insemination (days 2-6 after detection of a copulatory plug) in mice

\begin{tabular}{|c|c|c|c|c|c|c|c|c|c|c|}
\hline & $\begin{array}{l}\text { Number of } \\
\text { mice born }\end{array}$ & $\begin{array}{l}\text { After } \\
\text { day } 5\end{array}$ & $\begin{array}{l}\text { After } \\
\text { day } 4\end{array}$ & $\begin{array}{l}\text { After } \\
\text { day } 3\end{array}$ & $\begin{array}{l}\text { After } \\
\text { day } 2\end{array}$ & $\begin{array}{l}\text { After } \\
\text { day } 1\end{array}$ & $\begin{array}{l}\text { Before } \\
\text { day } 5\end{array}$ & $\begin{array}{l}\text { Before } \\
\text { day } 4\end{array}$ & $\begin{array}{l}\text { Before } \\
\text { day } 3\end{array}$ & $\begin{array}{l}\text { Before } \\
\text { day } 2\end{array}$ \\
\hline \multicolumn{11}{|l|}{ Oestradiol } \\
\hline $\begin{array}{l}\text { Before day } 1 \\
\text { Before day } 2 \\
\text { Before day } 3 \\
\text { Before day } 4 \\
\text { Before day } 5 \\
\text { After day } 1 \\
\text { After day } 2 \\
\text { After day } 3 \\
\text { After day } 4 \\
\text { After day } 5\end{array}$ & $\begin{array}{l}+0.08 \\
+0.01 \\
-0.18 \\
+0.20 \\
+0.23 \\
+0.33 \\
-0.59^{*} \\
-0.21 \\
-0.21 \\
+0.12\end{array}$ & $\begin{array}{l}+0.03 \\
-0.17 \\
-0.00 \\
+0.03 \\
-0.19 \\
-0.06 \\
-0.07 \\
+0.09 \\
+0.33\end{array}$ & $\begin{array}{l}+0.28 \\
+0.33 \\
+0.06 \\
+0.43 \\
+0.30 \\
+0.26 \\
+0.25 \\
+0.53\end{array}$ & $\begin{array}{l}+0.25 \\
-0.14 \\
-0.33 \\
+0.41 \\
-0.07 \\
+0.03 \\
+0.12\end{array}$ & $\begin{array}{l}+0.14 \\
+0.07 \\
+0.21 \\
+0.07 \\
+0.00 \\
-0.24\end{array}$ & $\begin{array}{l}+0.36 \\
+0.54 \\
+0.06 \\
+0.29 \\
+0.75^{*}\end{array}$ & $\begin{array}{l}+0.30 \\
+0.55 \\
+0.24 \\
+0.45\end{array}$ & $\begin{array}{l}+0.29 \\
+0.06 \\
-0.05\end{array}$ & $\begin{array}{l}-0.28 \\
+0.35\end{array}$ & +0.23 \\
\hline \multicolumn{11}{|l|}{ Testosterone } \\
\hline $\begin{array}{l}\text { Before day } 1 \\
\text { Before day } 2 \\
\text { Before day } 3 \\
\text { Before day } 4 \\
\text { Before day } 5 \\
\text { After day } 1 \\
\text { After day } 2 \\
\text { After day } 3 \\
\text { After day } 4 \\
\text { After day } 5\end{array}$ & $\begin{array}{l}+0.04 \\
-0.01 \\
+0.05 \\
+0.08 \\
+0.20 \\
+0.18 \\
-0.33 \\
+0.03 \\
+0.07 \\
+0.21\end{array}$ & $\begin{array}{l}+0.22 \\
+0.35 \\
+0.51 \\
+0.43 \\
+0.08 \\
+0.33 \\
-0.09 \\
+0.35 \\
+0.38\end{array}$ & $\begin{array}{l}+0.51 \\
+0.42 \\
+0.58^{*} \\
+0.73^{*} \\
+0.61^{*} \\
+0.49 \\
+0.08 \\
+0.77^{*}\end{array}$ & $\begin{array}{l}+0.51 \\
+0.36 \\
+0.54 \\
+0.79^{*} \\
+0.54 \\
+0.79^{*} \\
+0.25\end{array}$ & $\begin{array}{l}+0.15 \\
+0.35 \\
+0.33 \\
+0.27 \\
+0.08 \\
+0.31\end{array}$ & $\begin{array}{l}+0.50 \\
+0.55 \\
+0.69^{*} \\
+0.70^{*} \\
+0.55\end{array}$ & $\begin{array}{l}+0.64^{*} \\
+0.54 \\
+0.39 \\
+0.61^{*}\end{array}$ & $\begin{array}{l}+0.54 \\
+0.55 \\
+0.75^{*}\end{array}$ & $\begin{array}{l}+0.25 \\
+0.66^{*}\end{array}$ & $+0.59^{*}$ \\
\hline \multicolumn{11}{|l|}{ Progesterone } \\
\hline $\begin{array}{l}\text { Before day } 1 \\
\text { Before day } 2 \\
\text { Before day } 3 \\
\text { Before day } 4 \\
\text { Before day } 5 \\
\text { After day } 1 \\
\text { After day } 2 \\
\text { After day } 3 \\
\text { After day } 4 \\
\text { After day } 5\end{array}$ & $\begin{array}{l}+0.31 \\
+0.13 \\
+0.19 \\
+0.22 \\
+0.34 \\
+0.38 \\
-0.02 \\
-0.05 \\
+0.14 \\
+0.19\end{array}$ & $\begin{array}{l}-0.15 \\
+0.17 \\
+0.47 \\
-0.08 \\
+0.18 \\
+0.14 \\
+0.11 \\
+0.21 \\
+0.28\end{array}$ & $\begin{array}{l}+0.14 \\
+0.24 \\
+0.07 \\
+0.36 \\
+0.40 \\
+0.55 \\
+0.16 \\
+0.86^{*}\end{array}$ & $\begin{array}{l}+0.08 \\
+0.35 \\
+0.15 \\
+0.37 \\
+0.52 \\
+0.50 \\
+0.11\end{array}$ & $\begin{array}{l}-0.11 \\
+0.44 \\
+0.23 \\
+0.30 \\
+0.20 \\
+0.05\end{array}$ & $\begin{array}{l}+0.13 \\
+0.68^{*} \\
+0.51 \\
+0.45 \\
+0.74^{*}\end{array}$ & $\begin{array}{l}+0.28 \\
+0.79^{*} \\
+0.62^{*} \\
+0.64^{*}\end{array}$ & $\begin{array}{l}+0.36 \\
+0.45 \\
+0.44\end{array}$ & $\begin{array}{l}-0.11 \\
+0.57^{*}\end{array}$ & -0.04 \\
\hline
\end{tabular}

A positive sign indicates a positive correlation, whereas a negative sign indicates an inverse correlation.

*Two-tailed probability $<0.01$.

after insemination factor as within-subjects repeated measures. There were no significant effects for oestradiol. For testosterone, there was a significant interaction between day of measurement and the before versus after insemination factor, $F(4,171)=3.36, P=0.011$. Multiple comparisons (Duncan's new multiple range test, $P<0.05)$ indicated that the first measurement before insemination significantly exceeded all other measurements except the measurement after the final insemination, and that the final measurement after insemination significantly exceeded the measurements from the previous 2 days. For progesterone, there was a clearly significant effect of the before versus after insemination factor, $F(1,171)=37.33, P<0.0001$, but no other significant effects.
Of 20 female mice in which copulatory plugs were detected, 16 were parturient. Eighteen of the 20 female mice were observed to have built nests during week 2 after insemination; the other two female mice were among the non-parturient females. During days 1-2 after birth, three of the parturient female mice completely cannibalized their litters and one other female cannibalized part of her litter. The mean $( \pm$ SE) number of pups among parturient females was $9.81 \pm 1.01$ and the mean number of pups surviving on day 3 was $8.06 \pm 1.43$. Pearson product-moment correlations calculated between the number of pups born and each daily steroid measurement and among measurements within each steroid for 20 inseminated females, (zero was assigned to non-parturient females) are shown (Table 1). 
Table 2. Pearson product-moment correlations among steroid measurements (oestradiol, progesterone and testosterone) on mouse urine samples before insemination and after insemination

\begin{tabular}{lccc}
\hline & Oestradiol-progesterone & Oestradiol-testosterone & Testosterone-progesterone \\
\hline Before day 1 & +0.441 & $+0.823^{*}$ & +0.154 \\
Before day 2 & $+0.667^{*}$ & $+0.624^{*}$ & +0.267 \\
Before day 3 & +0.377 & +0.145 & +0.342 \\
Before day 4 & +0.496 & +0.348 & +0.167 \\
Before day 5 & $+0.772^{*}$ & $+0.728^{*}$ & +0.415 \\
After day 1 & $+0.650^{*}$ & $+0.736^{*}$ & +0.504 \\
After day 2 & +0.386 & +0.555 & +0.229 \\
After day 3 & +0.516 & $+0.636^{*}$ & +0.356 \\
After day 4 & $+0.657^{*}$ & $+0.748^{*}$ & $+0.608^{*}$ \\
After day 5 & $+0.909^{*}$ & $+0.888^{*}$ & $+0.871^{*}$ \\
\hline
\end{tabular}

*Two-tailed probability $<0.01$.

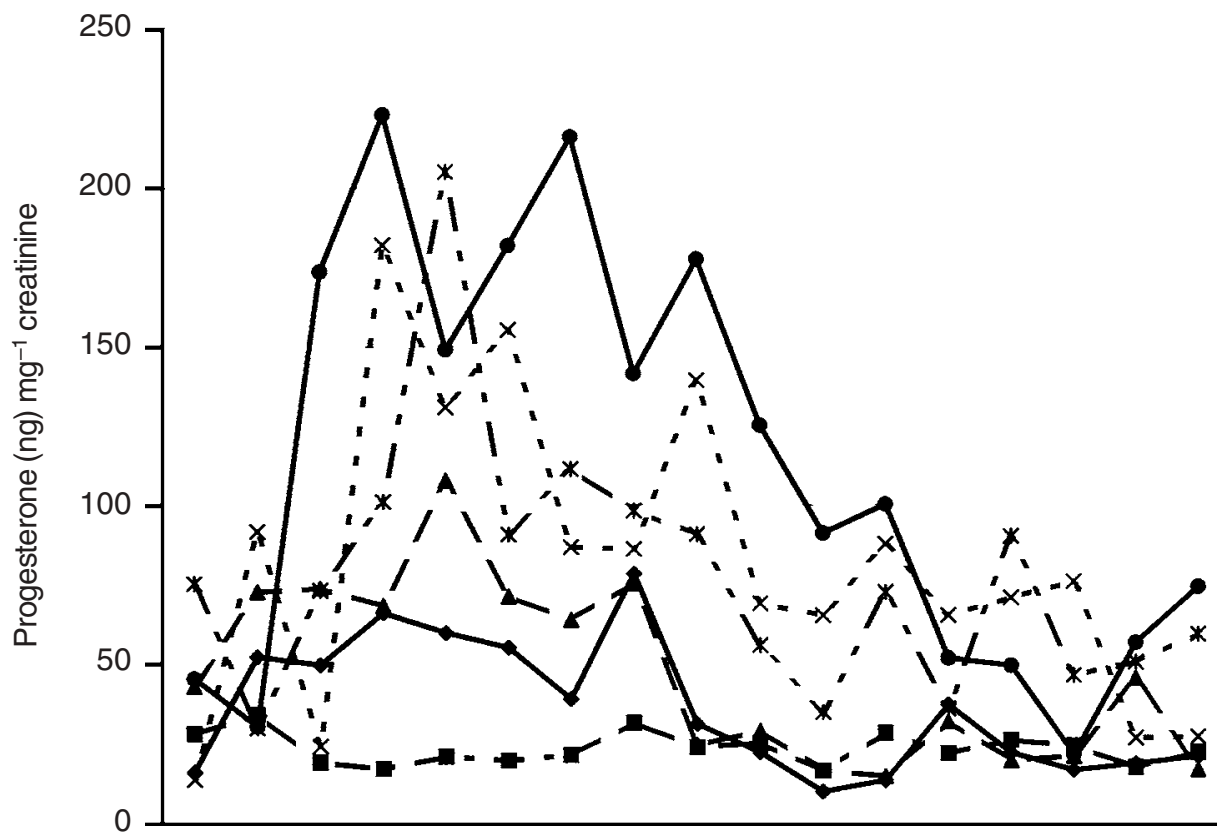

Fig. 5. Individual values of progesterone in daily urine measurements during days 2-18 of gestation for six inseminated female mice.

Correlations among repeated oestradiol measurements were generally lowest and correlations among repeated testosterone measurements were highest, indicating that oestradiol concentrations vary the most and testosterone the least over days within individuals. The number of pups born related clearly to only one steroid measurement, which was an inverse relationship to oestradiol concentrations on the second measurement after insemination. Correlations among the three steroid measurements were generally positive for measurements taken on the same day and not significant for comparisons across days; those for the same day are shown (Table 2).

Daily values of creatinine-adjusted urinary progesterone for six mice monitored from day 2 to day 18 of gestation are shown (Fig. 5). Overall values of progesterone varied among mice. Five of six mice showed a pattern of increased progesterone from day 3 or day 4 to day 10 of gestation with substantially lower values for the remainder of gestation. One of these mice had relatively low and invariant concentrations of urinary progesterone. All female mice were parturient and had litters in the range of $8-12$ live pups.

\section{Discussion}

A reliable and sensitive method for measuring variations in unconjugated oestradiol, testosterone and progesterone in mouse urine has been developed. Unlike procedures that require handling of animals and collection of blood samples, these methods permit repeated measurements and profiling of individuals over time. 
Insofar as urinary measurements reflect systemic action of these hormones, this may provide a non-invasive method to relate steroid dynamics to ongoing behaviour and development.

The most significant finding in the present study was that progesterone concentrations were substantially higher after insemination than before insemination. This finding was clearly significant in the first study and was then repeated in the second study in the individual profiles of urinary progesterone at days 2-18 of gestation. In the second study, there was clearly an increase in urinary progesterone from day 3 or day 4 to day 10 after detection of the copulatory plug for five of six mice. However, results from the one subject for which the progesterone concentrations were less dynamic during pregnancy cannot be accounted for, as this mouse produced a normal litter. The increase in urinary progesterone during pregnancy is generally consistent with the well-known systemic increase in progesterone during pregnancy. Nevertheless, unlike the current results, other reports indicate increased plasma progesterone during or up to late pregnancy, reaching a peak at about days 15-17 (McCormack and Greenwald, 1974; Pepe and Rothchild, 1974; Holinka et al., 1979), and similar profiles have been reported for rats (Barkley et al., 1979). The apparent discrepancies between blood and urinary concentrations of progesterone in late pregnancy could reflect strain differences, differential protein binding at different stages of pregnancy or various metabolic factors that have yet to be explored. Subsequent work should focus also on pregnanediol$3 \alpha$ glucoronide ( $c f$. Tyler et al., 1978); the ratio of conjugated and unconjugated progesterone during pregnancy potentially changes with stage of gestation.

In the measurements after insemination, progesterone concentrations did not show clear individual cycles, and there was a positive correlation over the 5 days. Variation of progesterone within individuals over the oestrous cycle might be obscured in part by sampling relative to a diurnal cycle ( $c f$. Michael, 1976; Bailey, 1987); proper characterization might require multiple measurements per day over several days. Oestradiol concentrations were more dynamic, showing low intraindividual correlations over days. In additional work (D. deCatanzaro, E. Beaton, C. Muir, M. Jetha and N. Laetsch, unpublished), we have observed clear cycling of urinary oestradiol within individuals over several successive days. Cell identifications in vaginal smears have indicated that the duration of the oestrous cycle in mice is variable and idiosyncratic, averaging about 4-6 days, but often not regularly recurring within a particular individual (for example, see Nobunaga, 1973; Barkley and Bradford, 1981; DeLeon et al., 1990).

The significant increase in testosterone in the fifth measurement after insemination (day 6 after detection of a copulatory plug) is consistent with the increase in plasma concentrations of this hormone that has been reported by Barkley et al. (1977, 1979). Otherwise, urinary testosterone was generally stable within individuals, showing quite high correlation values among daily samples.

The number of pups born was inversely related to oestradiol concentrations on the second measurement after insemination, which was approximately 70-80 h after mating, corresponding to intrauterine implantation of fertilized ova. Although oestrogen activity is clearly important for preparing of the uterus for implantation (Harper, 1992), high plasma oestradiol can cause disintegration of the corpus luteum (Greenwald, 1964), disrupt timing of arrival of fertilized ova at the uterus (Burdick and Whitney, 1937), produce suboptimal endometrial receptivity (Suginami, 1995) and induce oestrus via actions at the ventromedial hypothalamus (Pfaff, 1980).

Direct correlation of systemic and urinary steroid measurements for mice is limited in that blood sampling is too invasive to permit repeated systemic measures and subsequent urinary analysis, preventing full analysis of time lags between blood and urinary measurements. Unconjugated hormones as measured in urine in this laboratory do reflect some well-established systemic patterns. Systematic declines in urinary testosterone are observed after castration of males (Vella and deCatanzaro, 2001). Urinary oestradiol shows dynamic variation in cyclic females. As evident in data from the current study, urinary progesterone is substantially lower in samples from ovariectomized females than in those from intact females, and significantly increased in pregnant females to concentrations above those measured before insemination.

This research was supported by grants from the Natural Sciences and Engineering Research Council of Canada (NSERC) awarded to D. deCatanzaro.

\section{References}

Abraham GE (1969) Solid-phase radioimmunoassay of oestradiol-17 $\beta$ Journal of Clinical Endocrinology and Metabolism 29 866-870

Bailey KJ (1987) Diurnal progesterone rhythms in the female mouse Journal of Endocrinology 112 15-21

Barkley MS and Bradford GE (1981) Estrous cycle dynamics in differen strains of mice Proceedings of the Society for Experimental Biology and Medicine 167 70-77

Barkley MS, Michael SD, Geschwind II and Bradford GE (1977) Plasma testosterone during pregnancy in the mouse Endocrinology 1001472 1475

Barkley MS, Geschwind II and Bradford GE (1979) The gestational pattern of estradiol, testosterone and progesterone secretion in selected strains of mice Biology of Reproduction 20 733-738

Brown JL, Wasser SK, Wildt DE and Graham LH (1994) Comparative aspects of steroid hormone metabolism and ovarian activity in felids, measured non-invasively in feces Biology of Reproduction 51 776-786

Bruce HM (1960) A block to pregnancy in mice caused by the proximity of strange males Journal of Reproduction and Fertility 1 96-103

Burdick HO and Whitney R (1937) Acceleration of the rate of passage of fertilized ova through the Fallopian tubes of mice by massive injections of an estrogenic substance Endocrinology 21 637-643

Carroll JB, Abbott DH, George LM, Hindle JE and Martin RD (1990) Urinary endocrine monitoring of the ovarian cycle and pregnancy in Goeldi's 
monkey (Callimico goeldii) Journal of Reproduction and Fertility $\mathbf{8 9}$ 149-161

deCatanzaro D (1988) Effect of predator exposure upon early pregnancy in mice Physiology and Behavior 43 691-696

deCatanzaro D and MacNiven E (1992) Psychogenic pregnancy disruptions in mammals Neuroscience and Biobehavioral Reviews 16 43-53

deCatanzaro D, MacNiven E and Ricciuti F (1991) Comparison of the adverse effects of adrenal and ovarian steroids on early pregnancy in mice Psychoneuroendocrinology 16 525-536

deCatanzaro D, MacNiven E, Goodison T and Richardson D (1994) Estrogen antibodies reduce vulnerability to stress-induced failure of intrauterine implantation in inseminated mice Physiology and Behavior $\mathbf{5 5}$ $35-38$

deCatanzaro D, Muir C, O'Brien J and Williams S (1995) Strange-maleinduced pregnancy disruption in mice: reduction of vulnerability by $17 \beta$-estradiol antibodies Physiology and Behavior 58 401-404

deCatanzaro D, Zacharias R and Muir C (1996) Disruption of early pregnancy by direct and indirect exposure to novel male mice: comparison of influences of preputialectomized and intact males Journal of Reproduction and Fertility 106 269-274

deCatanzaro D, Baptista MAS and Vella E (2001) Administration of minute quantities of $17 \beta$-estradiol on the nasal area terminates early pregnancy in inseminated female mice Pharmacology, Biochemistry and Behavior 69 503-509

DeLeon DD, Zelinski-Wooten MB and Barkley MS (1990) Hormonal basis of variation in oestrous cyclicity in selected strains of mice Journal of Reproduction and Fertility 89 117-126

Graham LH, Goodrowe KL, Raeside KI and Liptrap RM (1995) Non-invasive monitoring of ovarian function in several felid species by measurement of fecal estradiol-17 $\beta$ and progestins Zoo Biology 14 223-237

Greenwald GS (1964) Luteolytic effect of estrogen on the corpora lutea of pregnancy of the hamster Endocrinology 76 1213-1219

Harper MJK (1969) Estrogenic effects of dehydroepiandrosterone and its sulfate in rats Endocrinology $84229-235$

Harper MJK (1992) The implantation window Baillière's Clinical Obstetrics and Gynaecology 6 351-371

Holinka CF, Tseng Y-C and Finch CE (1979) Reproductive aging in C57BL/6J mice: plasma progesterone, viable embryos and resorption frequency throughout pregnancy Biology of Reproduction $201201-$ 1211

Hsu C-Y (1948) Influence of temperature on development of rat embryos Anatomical Record 100 79-90

McCormack JT and Greenwald GS (1974) Progesterone and oestradiol-17 $\beta$ concentrations in the peripheral plasma during pregnancy in the mouse Journal of Endocrinology 62 101-107
Michael SD (1976) Plasma prolactin and progesterone during the estrous cycle in the mouse Proceedings of the Society for Experimental Biology and Medicine 153 254-257

Muir C, Vella ES, Pisani N and deCatanzaro D (2001) Enzyme immunoassay of $17 \beta$-estradiol, estrone conjugates, and testosterone in urinary and fecal samples from male and female mice Hormone and Metabolic Research 33 653-658

Munro CJ, Stabenfeldt GH, Cragun JR, Addiego LA, Overstreet JW and Lasley BL (1991) Relationship of serum estradiol and progesterone concentrations to the excretion profiles of their major urinary metabolites as measured by enzyme immunoassay and radioimmunoassay Clinical Chemistry 37 838-844

Nobunaga T (1973) Establishment by selective inbreeding of the IVCS strain and related sister strains of the mouse, demonstrating regularly repeated 4-day estrous cycles Laboratory Animal Science 23 803-811

Pedhazur EJ (1973) Multiple Regression in Behavioral Research New York: Holt Rinehart and Winston

Pepe GJ and Rothchild I (1974) A comparative study of serum progesterone levels in pregnancy and in various types of pseudopregnancy in the rat Endocrinology 95 275-279

Pfaff DW (1980) Estrogens and Brain Function New York: Springer-Verlag

Rodbard D and Lewald JE (1974) Statistical quality control and routine data processing for radioimmunoassays and immunoradiometric assays Clinical Chemistry 20 1255-1270

Runner ML (1959) Embryocidal effect of handling pregnant mice and its prevention with progesterone Anatomical Record 133 330-331

Suginami H (1995) Endocrine regulation of early embryonic development and implantation Hormone Research (Supplement) 44 1-3

Tyler JPP, Edwards WR and Collins WP (1978) The measurement of steroid glucoronides in urine from mice to monitor gonadal function. I. Pregnanediol- $3 \alpha$ glucoronide as an index of progestogen output Endocrinology 103 2342-2348

Vella ES and deCatanzaro D (2001) Novel male mice show gradual decline in the capacity to disrupt early pregnancy and in urinary excretion of testosterone and $17 \beta$-estradiol during the weeks immediately following castration Hormone and Metabolic Research 33 681-686

Wiebold JL, Stanfield PH, Becker WC and Hillers JK (1986) The effect of restraint stress in early pregnancy in mice Journal of Reproduction and Fertility 78 185-192

Received 24 February 2003.

First decision 10 April 2003.

Revised manuscript received 30 April 2003.

Accepted 19 May 2003. 